\title{
A TUDOMÁNYOS DIGITALIZÁLÁS PÉLDATÁRA AZ EGYETEMI KÖNYVTÁRTUDOMÁNYI KÉPZÉS TÜKRÉBEN
}

\author{
FODOR JÁNOS
}

ELTE BTK KITI, egyetemi adjunktus

\begin{abstract}
ABSZTRAKT
A tanulmány a Valóságos könyvtár - könyvtári valóság II. konferencia digitalizálási szekciójának előadásait foglalja össze. A program csak ízelítőt adhatott a nemzetközi és hazai digitalizálási projektekből, trendekből. A közlemény kontextust nyújtó háttérként a szervező ELTE BTK KITI digitalizálási projekteket elemző kutatásainak eredményeit osztályozva és rendszerezve állítja párhuzamba az előadók által bemutatott eredményekkel. Az elhangzott előadások legfontosabb gondolatait kiemelve kísérletet tesz azok összegzésére, valamint a tudományos digitális kommunikáció folyamatának rétegeire vetíti a különböző intézményi digitalizálási koncepciókat. A felhalmozott tudáskincs archiválásától a sikeres új innovációk születéséig végigkövetve a digitális információk útját kimutatja, hogy a könyvtárosok szerepe továbbra is létfontosságú marad a tudományos kommunikációban. Az ELTE KITI oktatási projektjeit példaként fókuszba helyezve nyilvánvalóvá teszi, milyen jelentősége lehet ebben a könyvtáros szakemberek korszerủ képzésének.
\end{abstract}

A tudományos felfedezések, eredmények történelmünket formáló hatására gondolva leginkább a kapcsolatok, összefüggések, az egymásra ható, inspiráló ötletek jutnak eszünkbe, s tán kevésbé a kutatással töltött idő, a tudománynak szentelt sorsok, s még kevésbé a dokumentumokban rögzített szakirodalom, a könyvtárak által biztosított alapzat, melyre minden kor kutatója, tudós elméje támaszkodott, amikor saját látásmódját kialakította, majd önálló véleményét megformálta.

Amikor a jelen valóságos könyvtárára és könyvtári valóságára gondolunk, mintha csökkenne is a dokumentáltság jelentôsége: a régmúlt tudás közvetítése, hozzáférhetôvé tétele háttérbe kerül, s égetően friss feladatként a gondolatok, témák, motívumok összekapcsolódásának, szerveződésének, áramlásának leképezése, a hálózati kommunikáció igényeinek hatékony kielégítése és az automatizálás, a mesterséges intelligencia felhasználása kerül fókuszba. A háttérben, talán kevésbé látványosan, de változatlanul alapfeltétel marad az algoritmizálhatósághoz, gépi kiértékeléshez és intelligens forgalmazáshoz is nélkülözhetetlen digitális információtárak építése, a dokumentumok hozzáférhetővé tétele és rendezése.

A Valóságos könyvtár - könyvtári valóság II. konferencia digitalizálási szekciója élő példatárát adta az élő, múködő tudomány különböző szintjeihez szükséges szerepüket betöltő, magas szakmai színvonalú hazai digitalizálási és gyűjteményépítési projekteknek. 


\section{FODOR JÁNOS}

Ha a konferenciaszekció közönségének gyors panorámaképet felvillantó előadássorozatot a könyvtártudományi kutatás és felsőoktatás szemszögéből áttekintve kiegészítjük intézeti oktatási programunk hátterével, hitelt érdemlően bizonyithatjuk: a konferencián bemutatott részterületek a tudomány rétegzettségét, komplexitását illusztrálták, a valóságos könyvtárat mutatták és a 21. századi könyvtári valóságból adtak ízelítőt.

\section{Tudományos rétegzettség és interaktivitás}

A Valóságos könyvtár - könyvtári valóság II. konferencia szervezésében partner ELTE Egyetemi Könyvtár Tanácsterme adott helyszínt az esemény második délutánján rendezett, Tudományos rétegzettség és interaktivitás - gyüjteményi digitaliqálás címú szekciónak. Az ELTE BTK KITI képzési programjában is fontos gyakorlati szerepet betöltő digitalizálási projektek és tartalomszolgáltatás-elemző kurzusok felelőseként e sorok írója szekcióvezetőként is izgalommal és örömmel hívta pódiumra a digitalizálás hazai szakembereit és irányítóit, akik előadásaikban a tudományos digitalizálás különböző léptékű, de egyként értékes és fontos szintjeit képviselték. Ízelítôt adtak munkájukból az elmélyült kutatásra épülő aprólékos kézirat-digitalizálástól és filológiai igényű szövegkiadástól az intézményi, könyvtári digitalizálási stratégiákon és tömeges hozzáférhetôvé tételt célzó projekteken át a virtuális gyújtemény-reprezentációs fejlesztésekig, interaktív felülettervezési megoldásokig.

Kutatók, szakemberek és oktatók bő egy évtizede tisztában vannak vele, hogy a tömeges digitalizálás korába léptünk, amikor az érintett tudományterületek és szolgáltató szektorok képviselői mellett fokozatosan, de egyre érzékelhetőbben átlépi a „hétköznapi ember” ingerküszöbét is a professzionális, programozott digitális tárak létezése.

Magyarországon a MEK és a nagy könyvtárak további digitális gyűjteményei, az Arcanum dokumentumtárai és az egyetemek repozitóriumai kettős helyzetet teremtenek: az átlagfelhasználóban egyre inkább tudatosul, hogy - ha nem is teszik gyakran, de - van hova fordulniuk otthonról vagy a telefonjuk képernyőjén keresztül: léteznek nagyszabású digitalizálási projektek a magyar kultúra és tudomány örökségének hozzáférhetôvé tételére. A könyvtárosok pedig a fejlődés eredményeként elfogadják, hogy a dokumentumok közzétételére e digitális dokumentumtárak kínálják a korszerű, hatékony, hosszú távon fejleszthető gyakorlatot. Számolnunk kell azonban annak veszélyeivel is, hogy a hagyományosan sokszintû tájékoztatás könyvtári feladatkörét mindkét szemszög megkérdőjelezheti. Az olvasók kevésbé igénylik a könyvtártól, hiszen személyes, virtuális eszköztáruk részeként létező, jól kereshető, elérhető archívumokat tételeznek, a létrejött befogadó digitális tárak pedig előre tervezett automatizmusuk okán nem is számol(hat) nak azzal a közvetlen, rugalmas és személyes tájékoztató kapcsolattal, amely egy-egy gyüjteményrész és szakértő könyvtárosai között korábban múködött.

A többszintű tájékoztatás könyvtártudományi és szakmai kihívása, hogy a lassanként összeálló, digitális tárak alkotta rendszer elemeiből a weben, közösségi médiában is hatékonyan és tudatosan biztosítsa az olvasó, könyvtárhasználó közönség utánpótlását, a tájékozott, források és tudásszintek között eligazodó nemzedékek folytonosságát.

Könyvtáros hallgatóink és szekciónk közönsége számára ezért is volt kiemelten érdekes az intézményi digitalizálási feladatok összetettsége, hiszen minden nagy könyv- 
tárunk szembesül a hálózati tájékoztatás, dokumentumtár-építés és számítógépes munkafolyamatok folyamatosan változó kihívásaival, s válaszaiban komplex megoldások keresésére kényszerül évrôl-évre.

\section{Azintézményi digitalizálás szintje}

Konferenciánk részprogramját két intézményi digitalizálási stratégia bemutatása foglalta keretbe: Varga Klára osztályvezető (ELTE Egyetemi Könyvtár Informatikai és Fejlesztési Osztály) történeti aspektusban vezette elő az Egyetemi Könyvtárban zajló digitalizálási munka állomásait. A több évtizedet átfogó nyitó előadás alkalmas volt a hátráltató tényezők, párhuzamos fejlesztési kísérletek józan számbavételére, s a technológiai és társadalmi fejlődés támasztotta kívánalmak újra átélésére is.

A záróelőadásban ezzel szemben Győrffy Szabolcs osztályvezető (Országos Széchényi Könyvtár Digitalizáló Osztály) elsősorban a mennyiségi, kapacitási kérdéseket érzékeltette hatásosan, meggondolandó kérdéseket felvetve a nemzeti digitalizálási stratégia könyvtári összehangolása és finanszírozása kapcsán.

A két előadás képzési programunk tükrében is különösen fontos volt, hiszen intézményi kapcsolataink között kiemelt helyen szerepel e két könyvtárral érvényes és termékeny együttmúködési megállapodásunk.

A képzett, tudása kontextusára rálátó, sokoldalú szakember-utánpótlás biztosítása érdekében a felsőoktatás különösen kényes és felelősségteljes feladata, hogy a szűkös oktatási időkeretben egyensúlyt tudjon tartani elméleti háttér, általánosítható modellek és eljárások, illetve eseti megoldások, különböző intézményekben kialakult gyakorlatok bemutatása között.

Az ELTE könyvtártudományi képzéséhez kapcsolódó gyakorlatok teljes rendszeréről tavaly publikált átfogó elemzést intézetigazgatónk ${ }^{1}$. A tartalomszolgáltatási és digitalizálási műhelymunka fontos része a bevált gyakorlatok megismerése. Intézetünk igazgatója, Kiszl Péter 2013-ban szakmai együttmúködési keretmegállapodást kötött az Országos Széchényi Könyvtárral ${ }^{2}$. A nemzeti könyvtár főigazgatójával közösen aláírt dokumentum célja az volt, hogy a gyakorlatban alkalmazott szakmai eljárásokat elemezhessük és mutathassuk be az egyetemi oktatásban, valamint a szakmai gyakorlatok hatékonyságát növeljük a könyvtárban.

Az együttmúködés keretében intézeti kurzuson, az OSZK egy munkatársának személyes közremúködésével ismertük meg az ott kifejlesztett egyedi informatikai eljárásokat, illetve a tanegység hallgatói az OSZK-ban töltötték szakmai gyakorlatukat, ezzel is erősítve a két intézmény közötti szinergikus kapcsolatot. Az együttmúködés első félévében az E-könyvtári Szolgáltatások Osztályának tevékenységét ismerhették meg mesterszakos hallgatóink $A$ tartalomszolgáltatás es₹közrendszerei című kurzuson. Az E-könyvtári Szolgáltatások Osztályáról érkező munkatársak, Rónay Gabriella és Fecz Ágnes ismertették tevékenységük részleteit, viszonzásként mesterszakos hallgatóink vettek részt szakmai gyakorlatuk során az osztály tartalomfejlesztési munkájában. 


\section{FODOR JÁNOS}

\section{A piaci vállalkozások rétege}

Az ezredforduló után természetessé vált, hogy a tájékoztatás minden területén, így a könyvtárak, gyújtemények, információs szolgáltatások munkatársainak szaktudásában is fontos szerepet kapott a digitalizálás, a webtartalmak előallítása. A tartalomszolgáltató rendszerek által generált weboldalak forráskódjának részleges megértése, a formázó sablonok, stíluslapok írása-olvasása háttértudásként és az informatikus könyvtáros alapműveltség részeként megkerülhetetlen maradt, azonban 2005 és 2010 között, a Web 2.0-ként emlegetett hálózathasználatunkat átformáló korszakban végleg szétváltak a produktív tartalomszolgáltatás formai keretei és tartalmi szálai.

A tartalomszolgáltató rendszerek létrehozása, adatbázis-kapcsolatok, lekérdezések és komplex webfelületek programozása informatikai feladattá vált, informatikus, webprogramozó szakemberek, erre a területre specializálódott cégek bevonását igényli. A szolgáltatástervezés szakmai és tartalmi előkészítése, a létrejött vagy készen felhasználható tartalomszolgáltató eszközök testreszabása és hatékony használata viszont könyvtáros kompetencia marad, s az informatikus könyvtáros képzés komplex, önmagában is interdiszciplináris részterülete lett.

A hazai digitalizálás piaci oldala sem a megrendelések végtelen bőségéről ismert, de fontosabb szereplői kezdetektől elkötelezettek a tudományos, kulturális gyűjtemények digitalizálásában. Közülük a legismertebb cég, az Arcanum Adatbázis Kiadó ügyvezető igazgatója, Biszak Sándor kellő öniróniával mérte cége teljesítményét a Google feldolgozási kapacitásához, s lényegre törően mutatta be az Arcanum adatbázisok ${ }^{3}$, a HUNGARICANA és ADT+ kulisszatitkait, különlegességeit.

Oktatási programunkban a megvalósult gyakorlat vizsgálatának természetesen tágabb példakörét adják vendégelőadók, intézetünk együttmúködő partnereinek bemutatói. E kitekintést szolgálják a közös kutatások is, melyek sorában 2014-ben zártuk le az egyetemi könyvtárak közösségi médiajelenlétét elemző felmérést, ${ }^{4}$ s 2015 -től építjük nyilvántartásunkat a magyar nyelvű szövegtárak, digitális könyvtárak vizsgálataiból. Az időről-időre egységes kritériumok szerint tesztelt több mint hetven digitális gyüjtemény ${ }^{5}$ elemzése sem ad természetesen teljes képet, de szignifikáns mintaként már használható nemzetközi összevetésre, kutatások kezdőpontjaként.

A vizsgált gyűjtemények között az Arcanum munkájának eredményeként létrejött adatbázisokat is rendszeresen értékeljük, fejlesztési lépéseiket rögzítjük (a gyüjtemények megnevezése utáni évszám jelzi a már írásban is közreadott elemzések keltezését):

Arcanum Hungaricana gyújtőoldal | 2015

Képeslapok | 2015

Közgyűjteményi Könyvtár

Magyar Digitális Múzeumi Könyvtár

Evangélikus Digitális Tár | 2015 (lásd variánsát lejjebb: MEDIT)

Helyi Lapok adatbázis

Levéltári kiadványok 
Országgyúlési Könyvtár gyűjteményei

Népszámlálási Digitális Adattár - Központi Statisztikai Hivatal Könyvtára | 2016 Magyar Tudományos Akadémia Könyvtára

A Magyar Külügyminisztérium kiadványai

Az Eszterházy Károly Tanárképző Főiskola Könyvtára

Fôvárosi Szabó Ervin Könyvtár

Iskolai értesítők | 2016

Középkori okmánytárak | 2016

Egyházi dokumentumok | 2016

Híd- és útépítő könyvek | 2016

Levéltári iratok

Az MKP, MDP, MSZMP megyei (fővárosi) vezető testületi üléseinek jegyzőkönyvei, 1945-1989

Egyetemi jegyzőkönyvek | 2016

Budapest főváros közgyűlési jegyzőkönyvei 1873-1949 | 2016

Mapire - A Habsburg Birodalom történelmi térképei | 2015

A Középkori Magyarország Levéltári Forrásai (DL/DF)

Mária Terézia úrbéri tabellái

Régi Magyar Könyvtár (RMK) I. | 2015

Kitaibel Pál herbáriuma | 2015

Térképek | 2015

Levéltári iratgyújtemény

Királyi Könyvek | 2015

Archontológia | 2016

Urbáriumok és összeírások | 2016

\section{A Magyar Országos Levéltár adatbázisai}

A Magyar Országos Levéltár Digitális Könyvtára

A Középkori Magyarország Digitális Könyvtára | 2015

Királyi Könyvek - béta verzió

Urbaria Et Conscriptoriones

Térképtár

MTI „Kőnyomatos Hírek”

MSZMP KB AgitProp iratok a Magyar Országos Levéltárban

- Magyar Levéltári Portál - Önkormányzati levéltárak közös adatbázisa (gyűjtőoldal)

Levéltárak közös fond- és állagjegyzéke

Fôvárosi és megyei MDP és MSZMP iratok

Archontológia, névtárak

\section{Arcanum Digitális Tudománytár}

- Digitális Tudománytár 
FODOR JÁNOS

- Országgyúlési Napló, irományok, dokumentumok 1861-1990 | 2015

- Veszprém kataszteri térkép (1856) Google térképen

- Magyar Mezőgazdasági Múzeum képzőművészeti gyűjteményének katalógusa | 2015

- Az Egyetemi Könyvtár alapkatalógusa

- Jel-Kép 1980-2011 folyóirat | 2015

- Első világháborús hadszíntéri térképek | 2015

- Egyetemi tanácsülési jegyzőkönyvek

- A Sajtó 1927-1947 folyóirat és könyvtár

- Népszava 1873-2015 | 2016

- Nappali ház --múvészeti és irodalmi szemle 1989-1999 | 2015

- Magyar Zsidó Levéltár Iktatókönyvei | 2015

- Magyarországi Zsidó Hitközségek Iratai 1944, 1947, 1948

\section{Körkép a hazai digitaliqálási projektekeról}

Az Arcanum által felépített digitálistár-hálózat könnyen felismerhető, egységes arculattal és hasonló technológiai, navigációs infrastruktúrával rendelkezik. A tudományos munkát kétségtelenül megkönnyíti a viszonylagos uniformizáltság, de egyes részgyűjtemények közreadásakor nem lehet kifogásunk egyedi megoldások, testreszabott megvalósítás ellen sem. Vizsgálataink szempontrendszerét ennek megfelelően úgy alakítottuk ki, hogy a legkülönbözőbb kivitelű digitális tárak elemzésére, értékelésére is alkalmas legyen, elfogadva a különböző színvonalú, fejlettségű technológiák létjogosultságát is.

Egységes szempontrendszerünk az írásos látleletekhez az alábbiak szerint alakult:

Alapadatok a gyüjteményröl:

Szerepel-e, könnyen elérhető-e az adattár pontos megnevezése, a gyüjtemény nyitólapjának közvetlen URL-je, a gyújtemény definitív, rövid leírása?

Kideríthető-e a létrehozás dátuma, a tulajdonos, fenntartó vagy magába foglaló honlap, cég, intézmény megnevezése, a magába foglaló honlap gyüjteményhez vezető (pl. Gyüjtemények) aloldalának megnevezése és URL-je, egyéb cég, intézmény, személy (létrehozó, digitalizáló, fejlesztő, ha eltér és fellelhetô)?

Screenshots/képernyökép

Archiválás és fejlesztések felmérése érdekében képernyőképet rögzítünk a publikus gyűjteményi nyitólapról, a keresési felületről, a tételek listázásáról, egy-egy tétel megjelenítéséről és a kísérő adatok megjelenítéséről.

\section{Információszolgáltatás}

Találunk-e bemutatást, leírást:

- a gyűjteményről, történetéról, a tulajdonosról, a fenntartóról,

- szerzői jogi feltételekről, a digitalizálásáról, a webes rendszer fejlesztéséről, 
- a tételek típusairól, elérhető formátumokról, a gyűjtemény felépítéséről, navigációjáról, keresési és egyéb felhasználói lehetőségekről, munkatársakról, - a további fejlesztési tervekről?

- Vannak-e hírek, esetleg saját blog, vagy a gyújteményhez kapcsolódó rovat a magába foglaló honlapon?

Navigáció/struktúra/ webdesign:

Hogyan jelenik meg, miként kapcsolódik (oda-vissza linkek, közös felületek, menük):

- viszony az intézményhez (a domainnév tulajdonoshoz),

- párhuzamos szintek, további gyűjtemények az intézmény által közzétéve,

- a gyűjtemény belső felépítése: pl. nyitóoldal, keresési felület, segítség/leírás, tételmegjelenítések, tételek közötti lapozás, továbbkeresés, szűrés-szűkítés, hasonlók lekérése.

\section{Kinált formátumok}

Pl. pdf, kereshető pdf, jpg, png, html, php, doc, e-könyv formátumok; esetleg választható alternatívák:

- szöveges, képi, hang, videó.

\section{Meta-adatolás, leirrás, katalóguscédula-megjelenités}

- egységes-e az adattartalom? Ha igen, egy jellemző tétel leírásának kivonatolása: mit tudunk meg róla?

- Ha egyenetlen, változó: melyek jelennek meg mindegyiknél, melyek változékonyak?

- Dokumentumtípusonkénti eltérések meghatározása (kép, szöveg).

Web 2.0 eszközrendszer, interaktivitás

- Hírlevél feliratkozást kínálnak-e?

- RSS feed elérhető-e, könnyen megtalálható-e?

- Regisztrálás lehetősége, profil kialakítása biztosított-e?

- Testreszabhatóság, átrendezhetőség megjelenéseinek rögzítése.

- Kommentelési lehetőséget kínálnak-e a tételekhez?

- Közösségi közreműködés további formái tételenként / gyűjtemény-egész szinten (pl. címkézés, infó-hozzáadás, leírásbővítés).

\section{Közösségimédia-kompatibilitás}

- A digitális gyújtemény tételeinek megnyitásakor kapunk-e egyedi URL-t (megosztható tételt, tétel-oldalt)?

- Segítik-e a megosztást beágyazott paranccsal (pl. Facebook Like gomb) (hogy ne az URL-t kelljen kimásolni)? 
FODOR JÁNOS

- Van-e a vizsgált gyűjteménynek Facebook-oldala? Ha van, URL-t örökítsük meg! Követők, lájkolók száma. Posztok hozzávetőleges száma (db/hónap).

- Van-e a magába foglaló intézménynek Facebook-oldala? Ha van, URL-t örökítsük meg! Követők, lájkolók száma. Posztok hozzávetőleges száma (db/hónap).

- Ha van, megjelennek-e a gyújtemény tételei megosztásaik alapjaként?

Az oktatási programunk keretében megvizsgált gyűjteményegyüttes ismerete nemcsak hallgatóink széleskörű tapasztalatszerzéséhez kötelező példatár, hanem a létező projektek számontartása nélkülözhetetlen a hazai digitalizálás olvasói és szakmai felméréséhez is. Azzal, hogy weboldalunkon időről-időre fejlődésükrôl is látleletet adunk, hosszabb távon, reményeink szerint a könyvtáros szakma érdeklődésére is számíthatunk.

A projekt indulása óta - a már felsorolt Arcanum adatbázisokon kívül - az alábbi gyűjtemények kerültek közös elemzésre hallgatóink elé (a vizsgált gyüjtemények megnevezése után évszám jelöli a már elkészült, publikált látleletek keltezését):

\section{Legfontosabb mühelyek munkái:}

MANDA

- Magyar Nemzeti Digitális Archívum

- Adatbázis | 2015

- Cikkek, gyüjtemények, szolgáltatások | 2016

- Filmhíradók Online | 2015

OSZK - Országos Széchényi Könyvtár

- Bibliotheca Corviniana Digitalis | 2015

- OSZK Digitális Képarchívum | 2015

- Magyar Digitális Képkönyvtár | 2016

- Magyar Elektronikus Könyvtár | 2015 | 2015

- Elektronikus Periodika Archívum | 2015

- OSZK Digitális Könyvtár | 2016

- OSZK Virtuális kiállítások | 2016

- OSZK Virtuális kiállítások - Örkény István - honlap | 2015

- Országos Széchényi Könyvtár - 1956-os Intézet és Oral History

Archívum | 2016

OSA

- Open Society Archive

- Virtuális diafilmmúzeum | 2015

- Fortepan | 2015

- Magyar Rendőr fotóarchívum | 2015

- Digital 1956 Archívum | 2016 
Petőfi Irodalmi Múzeum

- PIM projektek

- Digitális Irodalmi Akadémia | 2015

- Digitális filológiai projekt

Fővárosi Szabó Ervin Könyvtár

FSZEK Budapest Gyüjtemény | 2015

- Budapesti Czim- és Lakásjegyzék | 2015

Educatio Kht.

- (Kempelen Farkas) Digitális tankönyvtár (2005-) (Wikipédia szócikk) | 2015

Könyvtárak, tudástárak projektjei:

KSH Könyvtár - Tudásbázis | 2015 | 2016

Szlovákiai Magyar Adatbank | 2016

REAL-d MTAK - az MTA Könyvtár repozitóriuma | 2016

II. Rákóczi Ferenc Megyei Könyvtár - Borsodi Digitális Könyvtár | 2015

Verseghy Ferenc Elektronikus Könyvtár - Verseghy Ferenc Megyei Könyvtár | 2015

Jász-Nagykun-Szolnok Megyei Képeslaptár - Verseghy Ferenc Megyei Könyvtár | 2015 | 2016

Digitális Könyvtár - Dr. Kovács Pál Megyei Könyvtár | 2015

Vasi Digitális Könyvtár - 2015

Békés Megyei Elektronikus Könyvtár | 2016

Budaörsi Elektronikus Könyvtár | 2015

Kemenesaljai Digitális Könyvtár - Kresznerics Ferenc Könyvtár | 2015

Magyar Evangélikus Digitális Tár (MEDiT) | 2015 (Lásd variánsként az Arcanum Hungariacana részeként)

OMGK Digitalizált mezőgazdasági szakkönyvek könyvtárunk archív gyújteményéből | 2016

Pest Megyei Könyvtár | 2016

Vajdasági Magyar Digitális Adattár | 2015

Digitális Könyvtár - Kolozsvár

Erdélyi Digitális Adattár

Erdélyi Magyar Elektronikus Könyvtár | 2015

Egyetemek dokumentumtárai, repozitóriumai:

ELTE EDIT / ELTE EK Kézirat- és Ritkaságtár | 2016

SZTE Contenta | 2016

Corvinus Kutatások repozitórium | 2015 
FODOR JÁNOS

Corvinus Doktori disszertációk | 2016

Digitália - PTE EK | 2015

Kolozsvári Központi Egyetem Könyvtár - Digitális Gyűjtemény | 2015 | 2016

MIDRA - Miskolci Egyetem | 2015 | 2016

MOME Könyvtár/Design Portal | 2015

DEA - Debreceni Egyetemi Elektronikus Archivum | 2015 | 2016

DE Egyetemi és Nemzeti Könyvtár (archív, lezárt)

SZIE - Hungarian Electronic Journal of Sciences | 2015

Széchenyi István Egyetem E-tananyag + Szakdolgozat + Disszertációk | 2016

Testnevelési Egyetem - Digitális könyvtár | 2015

Levéltárak digitalizált anyagai:

Magyar Nemzeti Levéltár adatbázis oldala | 2015

Magyar Nemzeti Levéltár saját adatbázisai | 2015

Magyar Zsidó Múzeum és Levéltár | 2015

Magyar Zsidó Múzeum és Levéltár - Levéltári fondjegyzék | 2015

Borsod-Abaúj-Zemplén Megyei Levéltár | 2015

Múzeumok virtuális tárlatai:

Iparmûvészeti Múzeum | 2015

Jász-Nagykun-Szolnok Megyei Képeslaptár

Kuny Domokos Múzeum I. világháborús képeslapgyüjtemény | 2016

Lajta Béla Virtuális Archívum | 2016

MuseuMap | 2016

Erdélyi Digitális Adattár | 2016

Folyóiratok webváltozatai:

Holmi folyóirat - Teljes archívum 1989 - 2014 | 2015

Napút

Liget

Egyéb „magánkezdeményezések”, gyüjtemények és életmükiadások:

Antikfotó | 2016

Magyar Társadalomtudományok Digitális Archívuma | 2015

Csorba Győző emléklap | 2016

József Attila összes múve | 2016

Vészi Endre életműve

Fodor András életműve - ELTE BTK KITI 


\title{
Videótárak:
}

Videotorium | 2015

\author{
Nemzetközi kitekintés: \\ The European Library | 2016 \\ Project Gutenberg | 2016
}

Amint a felsorolásból látható, a hazai digitalizálás számtalan központban, múhelyben, részben összehangolatlanul és egymás tevékenységét is lefedve zajlik. Az elemzések eredményeit kiértékelni még korai lenne, de megállapítható, hogy a változatosság az informatikai, digitalizálástörténeti eltérések és technológiai szintkülönbségek mellett pozitív értelemben is megfigyelhető: kreatív, a gyüjteményekhez adoptált megjelenítések és dokumentum-interpretálások - ha kisebb számban is - a szabványosítás ellenében szóló példák lehetnek.

A gyűjtemények elemzésében a 2016-os őszi félévben Mátyás Melinda (Egyetemi Könyvtár) is közreműködik Intézetünk megbízott oktatójaként. Csoportjával az alábbi gyüjtemények vizsgálatára vállalkozott:

WDL (World Digital Library)
Hill Museum \& Manuscript Library
International Children's Digital Library
MDZ - Maps
Europeana
Palóc Múzeum
British Library - Sounds
Gbooks

Eredményeiket a Kutatási Napló felületén 2016 decemberében tesszük közzé.

\section{Technológia és kreativitás}

A konferenciaszekció piaci szereplői között, de a technológiai megoldások fejlesztését példázva szerepelt előadóként a Qulto - Monguz Kft.-t képviselő Brada Hedvig. A Qulto rendszerben ${ }^{6}$ rejlő közgyűjteményi attrakciófejlesztési lehetőségekről, a gamification területein elért eredményeikrôl, szolgáltatásépítési képességeikről tartott prezentációjával a legkorszerűbb trendekből adott ízelítőt, s csak remélhetjük, hogy a digitalizált tartalmak kreatív bemutatásának ilyen, s ehhez hasonló opciói a könyvtári szférában is tartalommal telítődnek a közeljövőben.

A piaci cég ismert alkalmazás típusaihoz (könyvtári és múzeumi integrált rendszereihez) köthető szolgáltatás terveit érdekes volt párhuzamba állítani a kulturális örökség hatékony közvetítésével kreatívan kísérletező MOME TechLab ${ }^{7}$ munkáival. A felsőoktatási múhely kutatói, Ruttkay Zsófia egyetemi docens és munkatársai digitalizált tartalmak prezentálásával foglalkoznak, a bemutatott egyedi interaktív felületek, demók és alkalmi, kiállításokhoz készült alkalmazások inspiráló ötletek sokaságát tartalmazzák. Képzési 


\section{FODOR JÁNOS}

programunk tükrében különösen izgalmasak voltak elképzeléseik és megoldásaik, hiszen mesterszakos hallgatóinkkal is azt vizsgáljuk, témák, tématerületek és tartalomszolgáltatási gyakorlat mentén hogyan szerveződnek a hálózati érdeklődés rétegei a felkeltett figyelemtől az utánaolvasásig, hogyan válik az elmélyülő felhasználó maga is tudását önszántából megosztó szerzővé, mi áll a tudatos tartalomszolgáltatóként fellépő, információt megosztó blogger, intézmény vagy erre szakosodott cég hatékonyságának hátterében?

A sikeres információszolgáltatás a 21. századi könyvtár számára éppen olyan fontos, mint a fizikai közösségi tér és benne a segítő környezet fenntartása. Mesterképzésben résztvevő hallgatóink már alapszakot végzett szakemberjelöltek, tisztában vannak korlátaikkal és lehetőségeikkel: kialakult jól felfogott tudományos szerénységük, ami gátolja óket, hogy saját nevükben professzionális tartalomszolgáltatást kezdeményezzenek, ugyanakkor képeseknek kell lenniük olyan témában modellezni a professzionális tartalomszolgáltatást, amelyben személyesen otthon érzik magukat, formálódó szakmai érdeklődésük része, kutatási területük, netán hobbijuk.

A képzési program digitálisgyűjtemény-elemzéseinek otthont adó munkafelülete a Kutatási Naplö ${ }^{8}$, mely egységes formában publikálja, illetve teszi elérhetővé a három féléves $A$ tartalomszolgáltatás es₹közrendszerei kurzus során végzett egyéni munkáikat is.

A modellezett helyzet komplex: a webhely egy kutatócsoport „work in progress” megjelenési felületeként, és olvasmányos, sokszínű témakörképként egyaránt olvasható, értelmezhető.

A tartalomszolgáltatás-elemző kurzushoz kapcsolódó gyakorlat célja az, hogy „kicsiben”, saját szolgáltatási projekten kipróbálhassák a megismert eszközrendszer által kínált lehetőségeket, a tartalom szerkesztését, publikálását, a figyelmet fenntartó közvetítést egy szabadon választott - de a célra megfelelő - témában.

A tématerület-elemrés során e téma webes megjelenését vizsgáljuk. Hogyan kommunikálódik, milyen változatait látjuk a témába vágó tartalomszolgáltatási gyakorlatnak, mit kíván meg egyedi sajátosságai szerint az adott téma, illetve az arra nyitott vagy általa megszólítható befogadó közönség? Mit tesz, vagy mit tehetne lehetővé a technológiai fejlődés, látunk-e felhasználható párhuzamokat más témában tartalmat szolgáltató projektekben? Milyen tanulságok vonhatók le a megismert gyakorlatból saját mini-projektünkre a valóságban, s a valóságtól (technológiai és finanszírozási lehetőségektől, programozói háttértől) elrugaszkodva? Milyen lenne az ideális tartalomszolgáltatás a választott téma-területen?

A Kutatási naplóban saját tartalomszolgáltatásaikat meglapozó és elemző, majd beindításukról beszámoló hallgatók munkáiból gyakran további művek, honlapok, egyetem után is folytatott kutatások származtathatók.

Példa erre a 2015. tavaszi félévéből az Intézetünk által közreadott Poesis Hungarica honlap ${ }^{9}$, mely Lukoviczki Anna hallgatónk munkájára, háttérkutatásaira épült ${ }^{10}$, vagy a 2016 őszén elkezdett Neonvadászat Budapesten, amelyben Prusinszki István alapszakos hallgató gyűjteményére építünk átfogó adatbázist. De hallgatóink OTDK és szakdolgozat témái, végzett szakemberként ôket jellemző kutatási tervek is rendre feltűnnek a kiadvány virtuális lapjain. 
A tartalomszolgáltatást és digitális gyűjteménykezelést elemző kurzusra számos szakkönyvtár, gyűjtemény munkatársát hívtuk meg ${ }^{11}$ olyan, korábban nálunk végzett, gyakorló könyvtári szakemberek személyében, akik vezető vagy operatív munkatársként aktív szerepet vállalnak gyüjteményük hálózati megjelenésében, webes szolgáltatások, digitális gyűjtemények fejlesztésében. Pályakezdés előtt álló hallgatóink számára tanulságos volt belelátni a Corvinus Repozitórium, a MEK és az EPA, vagy a Budapest Gyüjtemény admin felületén zajló napi tevékenységekbe, hallani az ELDORADO vagy a MOME repozitórium tervezésének komplexitásáról. Dávid Adrienne doktoranduszunk pedig a FSZEK Budapest Gyüjteménye helytörténeti tartalomszolgáltatásának - saját projektjeink kapcsán is tanulságos - múhelytitkaiba kínált bepillantást. A vendégelőadásokról részletes beszámolókat adtunk közre ${ }^{12}$, a megismert gyüjteményekről elkészített hallgatói elemzések pedig a Kutatási napló részévé váltak.

\section{Tudományos részprojektek, részgyüitemények - a kísérletezés jelentösége}

A tudományos digitalizálás legmélyebb rétegeit két aprólékos, nagy értékeket kis léptékben feltáró projekt képviselte. Szükségtelen hangsúlyozni, hogy munkájuk - noha eredményeik kevésbé látványosak - alapvető fontosságú: a tudományos örökség digitalizálásában, megjelenítésében és továbbörökítésében ôk biztosítják a megfelelő szakmai színvonalra példát adó mintát.

Tartalomszolgáltatási kutatásaink részese volt korábban Mátyás Melinda is, aki most az ELTE Egyetemi Könyvtár munkatársaként az ott végzett digitalizálási munka izgalmas részterületéről, a jezsuita tudósok kéziratainak feldolgozásáról számolt be, felmutatva a gyűjtemények elérhetővé tételéhez kapcsolható, lehetséges kutatási témákat.

2016 őszén vendégelőadónk volt Palkó Gábor (Petőfi Irodalmi Múzeum), aki a konferencián a DigiPhil projektből ${ }^{13}$ adott ízelítőt: a TEI XML alapú, szemantikus webtechnológiával felvértezett digitális filológiai megoldások a hozzáadott értékek tekintetében a digitalizálás legmagasabb szintjét képviselik. A szövegrétegek és adathálózatok megjelenítésével archiválható leghatékonyabban a tudás valóságos hálózata, öszszefüggésrendszere. Csak bízhatunk benne, hogy egyre több tudományos részterület feldolgozására lesz hasonló mélységben mód.

Az ELTE BTK Könyvtár- és Információtudományi Intézetének tartalomfejlesztési múhelye a kétezres évek közepétől kettős célt követ: miközben a tartalomszolgáltatás, a hálózati tájékoztatás eszközrendszerének vizsgálatát, elemzését is végzi, publicitásra érdemes, közös mintaprojektekbe vonja be a könyvtárosjelölt hallgatókat, hogy motiváló, kreatív munkavégzés közben sajátítsák el a korszerű könyvtáros szemlélet különböző vetületeihez kapcsolódó feladatokat. E cél érdekében a könyvtári gyűjteményi és tájékoztatási igényeket jól modellező, az interneten tájékozódók érdeklődésére reflektáló kisprojekteken dolgozunk hallgatóinkkal, melyek eredményei egyszerű - de tartalmi összefüggésekben teljes - formát öltve válnak a magyar nyelvű webtartalom részévé. ${ }^{14}$

Irodalomtörténeti, helytörténeti és könyvészeti mintaprojektjeink ${ }^{15}$ után 2015től intézményi együttmúködés keretében örömmel vontuk be hallgatóinkat jelentős és 


\section{FODOR JÁNOS}

bonyolult tartalmi szerkezetű történelmi gyűjtemények közzétételébe. Az ELTE BTK Könyvtár- és Információtudományi Intézete évek óta keresi az együttmúködés és aktív tapasztalatcsere területeit országos könyvtárakkal, bekapcsolva hallgatóink képzését a könyvtáros szakma élő gyakorlatába. ${ }^{16}$

A Fővárosi Szabó Ervin Könyvtárral 2015-ben kötött együttmúködési megállapodás keretében ${ }^{17}$ vettük fel a közvetlen munkakapcsolatot a Budapest Gyűjteménnyel is, amely 2015-ben, a Holokauszt-emlékévében a Könyvek holokausztja címú kiállításával járult hozzá a megemlékezések sorához. ${ }^{18}$ A Könyvek bolokausztja virtuális kiállítás fontos történelmi témát ábrázolt, nagyrészt a Budapest Gyűjtemény digitalizált képarchívumára építve. Örültünk az 1945-ös év történelmébe és irodalomtörténetébe vezető témának azért is, mert a műhelyünkben készített Fodor András Hálózati életmükiadás ${ }^{19}$ fél évszázadot átfogó időegyenese nagyjából ekkor - bár a fővárostól távoli Somogyban kezdődik, s a háború utáni Budapesten folytatódik.

Az együttmúködés újabb projektjeként 2016 őszén Pusztai Sándor - a Gellért fürdő hajdani úszómestere - hagyatékát, különleges fotógyüjteményét vettük át feldolgozásra a Budapest Gyűjteménytől. A félezer fénykép különleges értékét a harmincas évek ,úri közönségének” rendhagyó ábrázolása adja, erre utal a 2017 tavaszára elkészülő webgyűjtemény frivol munkacíme is: „Miniszterek gatyában”. A fürdőmester fényképein látható személyek beazonosítása igazi közösségi rejtvényfejtés lehet, s tartalomszolgáltatási feladatként izgalmas kihívás a közönséget nyomozásra, kutatásra ösztönző közreadás. Első lépésként történész szakértők bevonásával a könnyen felismerhető személyek azonosításával, a felvételek csoportosításával, osztályozásával foglalkozunk, majd háttérkutatásokkal a kort, társasági életet, fürdőkultúrát bemutató tartalmi elemekkel bővítve mutatjuk be a nagyközönségnek a teljes gyújteményt.

A szekcióprogramot szimbolikusan a digitális tudományosság fundamentális lépését bemutató program zárta: Cséka György (ELTE Egyetemi Könyvtár Közönségszolgálati Osztály) vezetésével vendégeink betekinthettek az Egyetemi Könyvtár elismert digitalizáló múhelyének munkájába, így a résztvevők a távlati, illetve az elmélyültebb fejlesztések prezentációi után a gyakorlati alapokból, a hardveres/szoftveres munkából is ízelítót kaphattak.

A szekció szakmai műhelyhangulatát a közönség aktivitása, a kérdések, hozzászólások száma is mutatta. Az érdeklődés és folyamatos figyelem bizonyította, hogy szükség és igény van a gyakorló szakemberek, oktatók és hallgatók konzultációjára, a jövőnket befolyásoló technológiai fejlesztések, stratégiák és megvalósult gyakorlatok közvetlen bemutatására. Elmélet, gyakorlás és megvalósult gyakorlat együttlátása, a tudományos kutatás és tudásreprezentálás rétegeinek felfedése nélkül lehetetlen érzékelni a tudomány múködésének valós komplexitását, valóságunkhoz kötöttségét.

Szekciónk, ahogy a Valóságos könyvtár - könyvtári valóság II. konferencia egésze, az egyetemi könyvtártudományi képzés tükrében így válhatott 2016 őszén a Tudomány igazi Ünnepévé. 


\section{Jegyzetek}

${ }^{1}$ KISZL Péter: Könyvtártudomány elméletben és gyakorlatban - intézményi együttműködés az Eötvös Loránd Tudományegyetemen. = Tudományos és Műszaki Tájékoztatás, 61. évf. 7-8. sz. 2014. 251-266. p.

${ }^{2}$ Szakmai együttmúködési megállapodás az OSZK-val. ELTE-LIS 2013.03.18. Forrás: http:/ [-] elte-lis.blogspot.hu/2013/03/szakmai-egyuttmukodesi-megallapodas-az.html [2016. szeptember 18.]

${ }^{3}$ Arcanum adatbázisok. Forrás: http://www.arcanum.hu/adatbazisok [2016. szeptember 6.]

${ }^{4}$ FODOR János: A megosztó hivatás: könyvtári jelenlét a Facebook közösségi oldalon 2013/2014-ben. = Tudományos és Műszaki Tájékoztatás, 61. évf. 7-8. sz. 2014. 275-294. p.

${ }^{5}$ Digitális Gyüjtemények = Kutatási Napló. Forrás: http://kutatasinaplo.blogspot.hu/p/[-] digitalibrary.html [2016. szeptember 6.]

${ }^{6}$ Qulto. Forrás: http://qulto.eu [2016. szeptember 8.]

${ }^{7}$ MOME TechLab. Forrás: http:// create.mome.hu [2016. szeptember 7.]

${ }^{8}$ Kutatási Napló. Forrás: http://kutatasinaplo.blogspot.hu [2016. szeptember 3.]

${ }^{9}$ Poesis Hungarica. Forrás: http://inaplo.hu/poesishungarica [2016. szeptember 18.]

${ }^{10}$ FODOR János: Poesis Hungarica digitális kontextusban. = Könyv, Könyvtár, Könyvtáros, 24. évf. 6. sz. 2015. 23-26. p.

${ }^{11}$ Tartalomszolgáltatás a gyakorlatban. ELTE-LIS 2015.06.24. Forrás: http:/ / elte-lis.blogspot.[-] hu/2015/06/tartalomszolgaltatas-gyakorlatban.html [2016. szeptember 9.]

${ }^{12}$ Vendégelőadók. Aktua'LIS - Fodor János blogja. Forrás: http://fodorjanos.blogspot.hu/[-] search/label/guest [2016. szeptember 11.]

${ }^{13}$ DigiPhil. Forrás: http://digiphil.hu [2016. szeptember 13.]

${ }^{14}$ FODOR János: Kollaboratív tartalomfejlesztési projektek az ELTE BTK Könyvtár- és Információtudományi Intézetében. = Tudományos és Műszaki Tájékoztatás, 62. évf. 11-12. sz. 2015. 429-441. p. Forrás: http://tmt.omikk.bme.hu/issue.html?issue_id=575 [2016. szeptember 9.]

${ }^{15}$ FODOR János: Poesis Hungarica digitális kontextusban. = Könyv, Könyvtár, Könyvtáros, 24. évf. 6. sz. 2015. 23-26. p.

${ }^{16}$ KISZL Péter: Könyvtártudomány elméletben és gyakorlatban - intézményi együttműködés az Eötvös Loránd Tudományegyetemen. = Tudományos és Műszaki Tájékoztatás, 61. évf. 7-8. sz. 2014. 251-266. p.

${ }^{17}$ Együttmúködés a Fővárosi Szabó Ervin Könyvtárral. ELTE-LIS 2015.09.02. Forrás: http:/ [-] elte-lis.blogspot.hu/2015/09/egyuttmukodesi-megallapodas-fovarosi.html [2016. szeptember 5.]

${ }^{18}$ Könyvek holokausztja. Üldözött írók, betiltott lapok, kirabolt könyvraktárak, megsemmisített könyvek. Forrás: http://www.fszek.hu/konyvtaraink/kozponti_konyvtar/budapest_[-] gyujtemeny/?article_hid=27561 [2016. szeptember 12.]

${ }^{19}$ FODOR János: A Fodor András hálózati életmúkiadásról. = Könyv, Könyvtár, Könyvtáros, 22. évf. 5. sz. 2013. 31-38. p.

Fodor János az ELTE Könyvtár- és Információtudományi Intézetének adjunktusa. Kutatásai központjában a könyvtárak közösségi média jelenléte áll. A hálózati publikálás és digitalizálás szakértője, egyetemi oktatója. Irodalmárként Fodor András Kossuth-dijas költő posztumusz köteteinek sorozatát rendezte sajtó alá, hátrahagyott életmúvéből a hallgatók bevonásával hálózati életmúkiadást hozott létre. 